Mariusz Tabaczek OP

Notre Dame Institute for Advances Study:

\title{
DUSZA LUDZKA W KONTEKŚCIE KLASYCZNEGO I WSPÓŁCZESNEGO HYLEMORFIZMU
}

\section{THE HUMAN SOUL ACCORDING TO CLASSICAL AND CONTEMPORARY HYLOMORPHISM}

Proponents of Aristotelian and Thomistic classical and contemporary (analytic) thought traditionally support and discuss hylomorphism and the concept of the human soul as a human being's substantial form. Recently, however, the number of proponents of hylomorphism among analytic metaphysicists (whose field is not connected with classical thought) has been increasing. This article examines the relationship between the new analytic understanding of hylomorphism and the classical definition of this concept. This article also takes up the issue of how these two understandings of hylomorphism apply to the current debate on the relationship between the mind and body and how they relate to the concept of the human soul.

Key words: human soul, analytic hylomorphism, classical hylomorphism, the human soul's intellectual powers, William Jaworski. 


\section{Wstęp ${ }^{1}$}

Jednym z najważniejszych zagadnień wewnątrz współczesnej debaty na temat istoty człowieczeństwa w filozofii analitycznej jest kwestia relacji umysł-ciało (mind-body problem). Jakkolwiek prawdą jest, że debata na ten temat w filozofii analitycznej jest złożona i zniuansowana ${ }^{2}$, jej przedstawiciele na ogół nie biorą pod uwagę i nie traktują poważnie klasycznego stanowiska zakładającego istnienie duszy ludzkiej. Ograniczeni kartezjańską dualistyczną wersją definicji duszy i jej relacji do ciała, zapominają o tym, że metafizyczny dualizm Kartezjusza nie jest jedynym tłem dla rozważań o duszy. Nie zwracają uwagi na to, że w świetle metafizyki i filozofii przyrody Arystotelesa i jego komentatorów, dusza ludzka - jako zasada aktualizująca materię pierwszą - jest zarówno gwarantem tego, że organiczne ciało człowieka jest ciałem ludzkim, jak również źródłem władz intelektualnych, które można odnieść do współczesnego pojęcia umysłu. Takie ujęcie duszy ludzkiej wydaje się być jak najbardziej dopuszczalnym i możliwym do obrony stanowiskiem $w$ debacie na temat relacji umysł-ciało.

Stanowisko, o którym mowa - odrzucone w filozofii pooświeceniowej przetrwało w myśli i nauczaniu filozofów i teologów wywodzących się z tradycji arystotelesowsko-tomistycznej. Co więcej, współcześnie jest ono prezentowane i komentowane nie tylko przez autorów określanych mianem klasycznych arystotelików lub tomistów, lecz także przez niektórych zwolenników realizmu i nowego arystotelizmu w metafizyce uprawianej w duchu analitycznym ${ }^{3}$ oraz tzw. tomizmu analitycznego ${ }^{4}$.

W ostatnim czasie, obok klasycznej i współczesnej (analitycznej) myśli arystotelesowskiej i tomistycznej - w kontekście coraz bardziej powszechnej tendencji kwestionującej podejście reduktywne zarówno w metafizyce, jak i w wybranych naukach szczegółowych - obserwujemy propozycję powrotu do hylemorfizmu, wychodzącą z kręgów współczesnej metafizyki analitycznej.

$1 \quad$ Niniejszy tekst jest zapisem referatu wygłoszonego w ramach konferencji Towarzystwa Teologów Dogmatyków poświęconej tematowi osoby i duszy ludzkiej w kontekście współczesnych neuronauk oraz debaty nad relacją umysł-ciało w filozofii analitycznej, w Lublinie 20 września 2017 roku.

2 Por. Dodatek.

3 Por. np. D. S. Oderberg, Real Essentialism, New York 2007; M. J. Loux, Aristotle's Hylomorphism, [w:] Neo-Aristotelian Perspectives in Metaphysics, D. D. Novotný, L. Novák (red.), New York 2014, s. 138-163.

4 Por. np. J. E. Brower, Aquinas's Ontology of the Material World: Change, Hylomorphism, and Material Objects, New York 2014; E. Feser, Scholastic Metaphysics: A Contemporary Introduction, Heusenstamm 2014; A. Kenny, Aquinas on Mind, London-New York 1993; J. D. Madden, Mind, Matter, and Nature: A Thomistic Proposal for the Philosophy of Mind, Washington D.C. 2013. 
Co więcej, przynajmniej jeden z prominentnych analitycznych metafizyków i filozofów umysłu, William Jaworski, twierdzi, że hylemorfizm jest najbardziej obiecującym rozwiązaniem $\mathrm{w}$ debacie nad zagadnieniem relacji umysł-ciało.

Czy jednak hylemorfizm w wydaniu filozofów analitycznych spoza kręgów arystotelesowsko-tomistycznych jest tożsamy z jego klasyczną definicją i tradycją interpretacyjną? Ponadto, czy zastosowanie tej wersji hylemorfizmu w kontekście analitycznej filozofii umysłu pozostaje w jakiejkolwiek relacji do klasycznego pojęcia duszy? Niniejsza prezentacja stanowi próbę odpowiedzi na oba pytania.

\section{Klasyczna definicja hylemorfizmu}

Pierwszym krokiem na tej drodze będzie przywołanie klasycznej definicji hylemorfizmu, co jest niezwykle istotne w kontekście pewnej trudności, na którą może natrafić każdy nowicjusz w studiach nad myślą Arystotelesa. Co więcej, wydaje się, że nie są od niej wolni także współcześni zwolennicy powrotu do hylemorfizmu wśród filozofów analitycznych. Otóż, w obu najbardziej popularnych i najczęściej cytowanych listach czterech przyczyn w Fizyce i Metafizyce Arystoteles - definiując przyczynę materialną - odwołuje się do przykładów posągu wyrzeźbionego w brązie oraz srebrnego naczynia (pucharu). W przykładach tych materia wydaje się być rozumiana odpowiednio jako brąz lub srebro, a forma jako kształt posągu lub naczynia (pucharu). Takie powierzchowne nawiązanie do myśli Stagiryty może prowadzić do ogólnego wniosku, że definiuje on materię jako fizykalny budulec (tworzywo), natomiast formę jako zewnętrzny kształt danego bytu ${ }^{5}$.

Wydaje się, że istnieją przynajmniej dwa powody, dla których Stagiryta sięga do wspomnianych i podobnych im przykładów. Pierwszy z nich ma charakter dydaktyczny. Wychodząc od tego co proste i intuicyjne, jako nauczyciel, Arystoteles pragnie doprowadzić swoich uczniów do zrozumienia tego, co wymaga myślenia abstrakcyjnego i spekulatywnego. Drugi powód dotyczy metodologii. Arystoteles wyznaje zasadę, iż tłumacząc stabilność i zmienność rzeczy w przyrodzie powinniśmy podawać zawsze i przede wszystkim przyczyny bliższe. Jednocześnie, obowiązek podawania przyczyn bliższych nie neguje realizmu przyczyn dalszych oraz tych najbardziej podstawowych i ogólnych, które leżą w samym sercu hylemorfizmu.

„W jednym przeto znaczeniu nazywa się przyczyną to, z czego coś powstaje i co trwa, np. brąz jest w tym sensie przyczyną posągu, a srebro naczynia” (Phys. II, 3 [194b 24-25]). „Przyczyną nazywa się, po pierwsze: (1) materia, z której coś powstaje, na przykład brąz jest przyczyną posągu, a srebro pucharu" (Meta. V, 2 [1013a 24-25]). 
I tak, w odniesieniu do przyczyny materialnej w złożeniu hylemorficznym, trzeba stwierdzić, iż ostatecznie nie jest nią empirycznie weryfikowalny materiał budulcowy (brąz czy srebro, itp. - określane mianem materii wtórej)

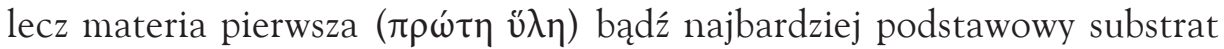

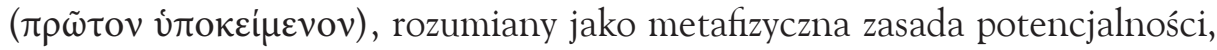
leżąca u podstaw każdego bytu i każdej zmiany w przyrodzie. Takie rozumienie przyczyny materialnej staje się oczywiste w świetle szeregu fragmentów $z$ dzieł Arystotelesa, jak chociażby jego słów z VII księgi Metafizyki, w których stwierdza: „Materią (ű $\lambda \eta$ ) nazywam to, co samo przez się nie jest ani określoną rzeczą, ani nie jest ilością, ani żadną inną kategorią określającą byt"6. Jeszcze bardziej pomocne jest w tym kontekście tłumaczenie Akwinaty z De principiis naturae w którym czytamy:

Brąz, chociaż stanowi materię w odniesieniu do posągu, to jednak sam jest złożony z materii i formy. A zatem brąz nie jest nazywany materią pierwszą, ponieważ sam posiada materię. Sama zaś materia, która jest rozumiana jako nieposiadająca jakiejkolwiek formy i braku (privatio), lecz podległa formie i brakowi (privatio), jest nazywana materią pierwszą, ze względu na to, że nie ma przed nią żadnej innej materii ${ }^{7}$.

Jeżeli chodzi o przyczynę formalną, to choć Arystoteles - we wspomnianych już popularnych listach czterech przyczyn w Fizyce i Metafizyce - określa ją za

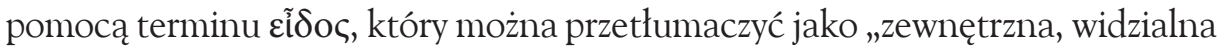
postać osoby lub przedmiotu", w centrum podanych przezeń definicji stoją dwa

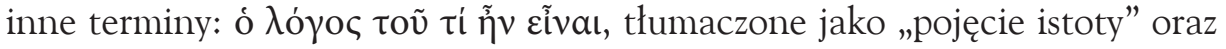

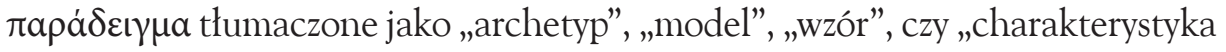
danego typu". Oba wyrażenia wskazują na to, że przyczyna formalna jest nie tyle zewnętrzną postacią czy geometrycznym kształtem, co raczej wewnętrzną metafizyczną zasadą aktualizującą materię pierwszą w danej substancji.

Co więcej, znane jest także zaproponowane przez Arystotelesa rozróżnienie między zmianą bytu, w której „mimo trwania podłoża, które jest dostrzegalne zmysłami, dokonuje się wymiana w warstwie jego przypadłości" (np. przejście organizmu ludzkiego ze stanu choroby do stanu zdrowia), a zmianą całkowitą, w której „nie pozostaje nic dostrzegalnego, będącego niejako jego podłożem” (np. zmiana drewna w popiół) $)^{8}$. W oparciu o tę dystynkcję, późniejsza tradycja

$6 \quad$ Meta. VII, 3 (1029a 21-22).

7 " $[$ S] icut aes, cum sit materia respectu idoli, ipsum tamen aes est compositum ex materia et forma; et ideo aes non dicitur materia prima, quia habet materiam. Ipsa autem materia quae intelligitur sine qualibet forma et privatione, sed subiecta formae et privationi, dicitur materia prima, propter hoc quod ante ipsam non est alia materia” (De prin. nat. 14), tłum. własne. 
rozróżnia formę substancjalną bytu - odpowiedzialną za jego bycie tym, czym jest - oraz formę przypadłościową (akcydentalną) - odpowiedzialną za cechy, które nie przynależą do istoty danego bytu, w związku z czym ich zmiana czy zanik nie powodują zmiany jego tożsamości.

$\mathrm{Na}$ koniec przedstawienia głównych zasad hylemorfizmu Arystotelesa należy podkreślić, że jakkolwiek teoria Stagiryty ma istotny rys dualistyczny, charakteryzujący ją dualizm jest dualizmem metafizycznych zasad racjonalnego opisu i wyjaśniania rzeczywistości, nie zaś dualizmem substancjalnym, na miarę kartezjańskiego rozróżnienia substancji rozciągłej i duchowej (umysłowej). Innymi słowy, możliwości spekulatywnego rozróżnienia zasad materialnej i formalnej, towarzyszy fakt ich nieredukowalnego wspólistnienia w otaczającej nas rzeczywistości bytów materialnych. Forma substancjalna występuje zawsze jako formująca materię pierwszą, podczas gdy materia pierwsza jest dostępna ludzkiemu poznaniu zawsze jako uformowana przez jakąś formę substancjalną9

\section{Dusza ludzka w ujęciu hylemorficznym}

Przechodząc do tematu zastosowania klasycznego hylemorfizmu w antropologii, zauważamy, że Arystoteles definiuje duszę (w dziele zatytułowanym O duszy) jako akt bądź formę ciała naturalnego (czy to roślinnego, czy zwierzęcego, czy ludzkiego), tj. zasadę sprawiającą, że ciało to jest bytem ożywionym (zdolnym do odżywiania się i wzrostu) ${ }^{10}$. Starając się uszczegółowić tę definicję, Arystoteles dodaje, że ciało, które jest w możności do bycia ciałem ożywionym musi być ciałem organicznym, tj. posiadać różnorodne części (őpyava = instrumenty), charakteryzujące się określoną aktywnością, ze względu na spełnienie przez dany byt ożywiony różnych funkcji życiowych ${ }^{11}$. Jednocześnie trzeba tu podkreślić, że to forma sprawia, iż ciało ma charakter organiczny, a nie ciało organiczne jest właściwym „podłożem” dla duszy organizmu żywego.

Zdając sobie z tego sprawę, św. Tomasz zwraca uwagę na pewien niezwykle istotny szczegól, który umyka wielu zwolennikom hylemorfizmu w antropologii. Chociaż Akwinata akceptuje popularny w jego czasach - ale także i dziś - język dualizmu mówiącego o relacji duszy ludzkiej do ciała (gdzie dusza jest określana

$9 \quad$ Wyjątkiem jest rzecz jasna dusza ludzka, o czym poniżej.

10 Święty Tomasz rozszerza tę definicję życia, stwierdzając, że pierwszym objawem posiadania życia jest zdolność ruchu - przy czym ruch rozumiany jest tu szeroko, tak, że jako rodzaj ruchu kwalifikuje się również działanie umysłu - co ma doniosłe znaczenie dla Tomaszowej antropologii filozoficznej i teologicznej. Zob. In De an. II, lect. 1 (§ 219).

11 „[D]usza jest «pierwszym aktem ciała naturalnego, które posiada w możności życie», czyli ciała obdarzonego organami" (De an. II, 1 [412a 35]). Por. także In De an. II, lect. $1(\$ 230)$. 
jako forma ciała) jednocześnie podkreśla fakt, iż - ściśle rzecz ujmując - dusza i ciało nie są metafizycznymi korelatami. Są nimi dusza i materia pierwsza, gdyż cielesność jako taka przynależy do materii właśnie z powodu duszy jako formy substancjalnej. W kontekście tego rozróżnienia św. Tomasz zauważa:

Nie powinno się zatem twierdzić, że dusza jest aktem ciała, oraz że ciało jest dla niej materią i przedmiotem, tak jakby ciało było ukonstytuowane przez jedną formę, która czyni je ciałem oraz dodaną do niej duszę, czyniącą je ciałem żywym. Raczej, powinno się uważać, że od duszy pochodzi zarówno to, że ciało jest, jak i to, że jest ciałem żywym. Bo to, że istnieje jako ciało (co jest czymś mniej doskonałym) jest czymś materialnym w odniesieniu do życia.

A zatem, po wyjściu duszy z ciała, nie pozostaje ono tym samym ciałem pod względem gatunkowym; tak że oczu i mięśni ${ }^{12}$ nie orzeka się w odniesieniu do zmarłego inaczej, jak tylko w sposób wieloznaczny, jak to pokazuje Arystoteles w VII księdze Metafizyki. Zatem, po wyjściu duszy z ciała w jej miejsce wchodzi inna forma substancjalna, która daje inne istnienie gatunkowe, jako że rozkład jednego [bytu] nie następuje bez powstania innego ${ }^{13}$.

\section{Władze intelektualne w hylemorficznej koncepcji duszy}

Wymieniając trzy możliwe rodzaje organizmów żywych: roślinny, zwierzęcy oraz ludzki, św. Tomasz przypisuje im właściwe zasady życiowe: wegetatywną, zmysłową, oraz umysłową. Skupiając naszą uwagę na tej ostatniej, zauważamy - wraz z Akwinatą - iż będąc podstawą najważniejszych dyspozycji i sprawności właściwych niższym organizmom, tzn. odżywiania się, odbierania wrażeń zmysłowych oraz ruchu w przestrzeni lokalnej, dusza ludzka jest także zasadą władz umysłowych. Ten fakt skłania św. Tomasza do postawienia śmiałej tezy mówiącej, iż „intelekt będący zasadą działalności umysłowej jest formą ciała ludzkiego" 14 .

12 Termin „mięsień” jest tłumaczeniem trudnego do oddania w tym kontekście łacińskiego słowa caro (ang. flesh).

13 Non ergo sic est intelligendum quod anima sit actus corporis, et quod corpus sit eius materia et subiectum, quasi corpus sit constitutum per unam formam, quae faciat ipsum esse corpus, et superveniat ei anima faciens ipsum esse corpus vivum; sed quia ab anima est, et quod sit, et quod sit corpus vivum. Sed hoc quod est esse corpus, quod est imperfectius, est quid materiale respectu vitae.

Et inde est quod recedente anima, non remanet idem corpus specie; nam oculus et caro in mortuo non dicuntur nisi aequivoce, ut patet per philosophum in septimo metaphysicorum. Recedente enim anima, succedit alia forma substantialis quae dat aliud esse specificum, cum corruptio unius non sit sine generatione alterius. In De an. II, lect. 1 (§ 225-226), tłum. własne. 
Święty Tomasz nie bez powodu przykłada tak wielką wagę do roli umysłu, określając duszę ludzką mianem duszy intelektualnej. Okazuje się bowiem, że to właśnie władze umysłowe czynią duszę ludzką wyjątkową nie tylko pośród wszystkich form naturalnych występujących w przyrodzie, ale także wśród zasad aktualizujących wszystkie pozostałe organizmy żywe (roślinne i zwierzęce). W odróżnieniu od władz zmysłowych, które - poznając za pośrednictwem cielesnego organu (instrumentu) - poznają formy jednostkowe innych bytów, władze umysłowe - dzięki umiejętności abstrakcji - mają także zdolność poznania istoty całych klas bytów. W związku z tym, władze intelektualne jako takie nie mają odpowiadającego im narządu poznania w organizmie człowieka. Z drugiej jednak strony, to, że poznanie istot rzeczy materialnych przez intelekt odbywa się na drodze abstrahowania od obrazów zmysłowych i wyobrażeń, czyni ciało doskonałym instrumentem duszy i sprawia, że jest ona z nim ściśle zjednoczona właśnie ze względu na swoją szczególną aktywność intelektualną ${ }^{15}$.

Wyjątkowy charakter duszy ludzkiej wyraża się także w tym, że będąc aktualizującą materię pierwszą zasadą formalną, ma ona jednocześnie w odniesieniu do posiadanych przez nią władz intelektualnych - zdolność przyjmowania form ${ }^{16}$. Należy przy tym zauważyć, że w przeciwieństwie do bytów czysto materialnych, dla których przyjęcie nowej formy oznacza de facto zmianę substancjalną i powstanie nowego bytu, tożsamość poznawcza intelektu $z$ formami innych bytów $\mathrm{w}$ akcie poznania nie prowadzi do utraty tożsamości i zmiany substancjalnej bytu ludzkiego. Fakt ten staje się podstawą argumentu na rzecz tego, że jedną z kluczowych cech charakterystycznych intelektu jest jego niematerialna nieokreśloność i otwartość, która pozostaje w relacji do niematerialnego i duchowego charakteru duszy ludzkiej ${ }^{17}$.

\section{Podstawy antropologii teologicznej św. Tomasza}

Wymienione cechy duszy, zdefiniowane w kontekście hylemorficznej antropologii filozoficznej Arystotelesa, stanowią punkt wyjścia dla oryginalnej i kompleksowej antropologii teologicznej św. Tomasza z Akwinu, w której

15 Por. In De an. III, lect. $7(\S 684,686)$. Tomasz dodaje w $§ 687$, że władze umysłowe różnią się od zmysłowych także w kwestii nieporuszalności w reakcji na fizykalne bodźce zewnętrzne. Ten fakt jest istotny dla zasadnego uznania samoistnego charakteru duszy ludzkiej, o czym wspomnimy pokrótce w kolejnej sekcji.

16 Por. In De an. III, lect. 7 (§ 686). Poznanie intelektualne form uniwersalnych, tj. przyjęcie, czy też odciśnięcie ich w umyśle - Tomasz odwołuje się w tym miejscu do analogii pieczęci odbitej w wosku - jest poprzedzone poznaniem zmysłowym, tj. przyjęciem form indywidualnych na podstawie poznania zmysłowego, w myśl klasycznej zasady „Nihil est in intellectu quod prius non fuerit in sensu".

17 Por. B. J. Shanley, Tradycja Tomistyczna, tłum. R. Mordarski, Poznań, s. 376. 
stwierdza, iż duszę ludzką charakteryzują: samoistność, bycie stworzoną, oraz nieśmiertelność. Ta ostatnia - ze względu na naturalną tendencję duszy do bycia w ciele (czy raczej [in] formowania/aktualizowania materii pierwszej w organizmie ludzkim) - jest podstawą Tomaszowego przekonania o nieśmiertelności ciała człowieka, co w efekcie czyni go nieśmiertelnym jako całą osobę. Problem ten jednak - jako wykraczający poza ramy niniejszej prezentacji - pominiemy.

\section{Hylemorficzna koncepcja człowieka w świetle problemu relacji umyst-ciało}

Hylemorficzna koncepcja człowieka stanowi oryginalną i wyważoną propozycję pozwalającą uniknąc dwóch skrajności w kontekście debaty na temat problemu relacji umysł-ciało. Z jednej strony, hylemorfizm antropologiczny (sam będąc dualizmem metafizycznym) radykalnie sprzeciwia się wszelkim formom dualizmu substancjalnego. Człowiek jest w jego ujęciu jednością materii pierwszej i formy substancjalnej, tj. duszy intelektualnej - rozumianych nie jako dwie odrębne substancje, lecz jako dwie komplementarne metafizyczne zasady racjonalnego wyjaśniania jedności i istoty bytu ludzkiego.

$\mathrm{Z}$ drugiej strony, ta sama pozycja hylemorfizmu antropologicznego pozwala uniknąć materializmu redukcyjnego. Jako zasada ożywiająca i forma ciała, dusza ludzka jest niematerialną zasadą metafizyczną, a jej korelatem jest materia pierwsza, o podobnym, pozafizykalnym charakterze. Unikając abstrakcji od materialnego aspektu organizmu ludzkiego, hylemorfizm antropologiczny nie pozwala na jego redukcję do obserwowalnych w nim podstawowych cząstek elementarnych ${ }^{18}$.

Unikając skrajności dualizmu substancjalnego i materializmu redukcyjnego, hylemorfizm antropologiczny oferuje konstruktywną odpowiedź na pytanie o rolę umysłu w odniesieniu do ciała. Według niego, umysł człowieka, nie będąc ani osobną substancją, ani użyteczną fikcją, jest unikalnym i szczególnym rodzajem władz duszy ludzkiej. Jako taki decyduje o jej wyjątkowym charakterze $\mathrm{w}$ porównaniu z zasadami formalnymi innych organizmów żywych ${ }^{19}$.

18 Dotykamy w tym miejscu Arystotelesowej i Tomaszowej koncepcji obecności prostych składników w złożonych bytach poprzez moce (virtute). Jej szczegółowa prezentacja wybiega poza ramy naszych obecnych rozważań.

19 W kontekście Tomaszowej antropologii hylemorficznej należy dodać, że to właśnie ze względu na naturę władz intelektualnych (umysłowych), dusza ludzka - pozostając w relacji ścisłego zjednoczenia z ciałem - jest jednocześnie zdolna do egzystowania poza ciałem; jakkolwiek stan ten nie jest dla niej stanem naturalnym i domaga się zmiany, tj. ponownego zjednoczenia się duszy z ciałem, czy raczej ponownego formowania materii pierwszej w organicznym ciele ludzkim. 


\section{Współczesne wersje hylemorfizmu w filozofii analitycznej}

Próba klasyfikacji współczesnych wersji hylemorfizmu w filozofii analitycznej prowadzi do wyróżnienia przynajmniej trzech najważniejszych propozycji jego reinterpretacji w pismach myślicieli wywodzących się z tej tradycji. Są to: (1) hylemorfizm mereologiczny lub strukturalny, (2) hylemorfizm komplementarystyczny, (3) hylemorfizm reidentyfikacyjny.

\section{Hylemorfizm mereologiczny lub strukturalny}

I tak, pierwsza, a zarazem kluczowa, współczesna interpretacja hylemorfizmu określa jego główne zasady: materialną i formalną, jako mereologiczne części jednej całości. Prezentując takie stanowisko, Kathrin Koslicki stwierdza, że forma - cechując się pierwotną jednością - jako mereologiczna część całości pełni funkcję jednoczącą pozostałe części danego bytu (rozumiane jako fizykalne jednostki budulcowe). W innym miejscu dodaje do swojej teorii aspekt strukturalny, definiując jedność substancji jako zajmowanie przez jej składowe właściwej pozycji (czasowo-przestrzennej) w strukturze bytu, który tworzą ${ }^{20}$.

W podobnym duchu hylemorfizm definiują Mark Johnston ${ }^{21}$, Kit Fine ${ }^{22}$ oraz William Jaworski, którego stanowisko interesuje nas szczególnie, ze względu na jego propozycję zastosowania hylemorfizmu w filozofii umysłu. W swojej książce zatytułowanej Structure and the Metaphysics of Mind: How Hylomorphism Solves the Mind-Body Problem Jaworski stwierdza, że „,hylemorfizm jest związany ze strukturą [bytów]”, dodając, iż „struktura (bądź też organizacja, forma, ułożenie, porządek, lub konfiguracja) jest podstawową zasadą w ontologii i wyjaśnianiu [rzeczywistości]" ${ }^{23}$, W nawiązaniu do dyspozycjonalizmu w metafizyce analitycznej Jaworski stwierdza, że „aktywność bytów cechujących się określoną strukturą wyraża się w skoordynowanej manifestacji mocy ich poszczególnych części”"24, co każe mu następnie stwierdzić, iż formy substancjalne są „strukturami odpowiedzialnymi za powstanie bytów jednostkowych” ${ }^{2}$.

20 Por. K. Koslicki, The Structure of Objects, Oxford 2010, rozdz. 6-7.

21 M. Johnston, Hylomorphism, "Journal of Philosophy" t. 103, nr 12 (2006), s. 652-698.

22 K. Fine, Things and Their Parts, "Midwest Studies in Philosophy" t. 23, nr 1 (1999), s. $61-74$.

23 " $[\mathrm{H}]$ ylomorphism is about structure (...) structure (or organization, form, arrangement, order, or configuration) is a basic ontological and explanatory principle". W. Jaworski, Structure and the Metaphysics of Mind: How Hylomorphism Solves the Mind-Body Problem, Oxford 2016, s. 8. Wszystkie tłumaczenia z języka angielskiego własne.

24 "[T]he activities of structured individuals involve coordinated manifestations of the powers of their parts" (ibidem, 5).

25 Mowa tu o "individual-making structures" (ibidem). 
Podobnie jak w przypadku Koslicki, Fine i Johnston, stanowisko Jaworskiego cechuje mereologiczne podejście do materii (definiowanej jako podstawowe fizykalne jednostki budulcowe), co stanowi radykalne odejście od jej rozumienia jako metafizycznej zasady potencjalności w klasycznej wersji hylemorfizmu. Co więcej, jego redefinicja formy substancjalnej w odniesieniu do struktury będącej kompozycją materiałów wchodzących w jej skład, rodzi zasadnicze pytanie o pierwszeństwo. Otóż, definiując kompozycję Jaworski stwierdza, iż „Z punktu widzenia hylemorfizmu, kompozycja ma miejsce wtedy i tylko wtedy, gdy jednostka (individual) konfiguruje lub strukturalizuje materiały"26. Tyle, że w myśl jego własnego stanowiska metafizycznego, złożony byt (jednostka) jest funkcją struktury (rozumianej jako forma substancjalna). Co jest, wobec tego, pierwsze: jednostka konfigurująca (strukturalizująca) materię, czy raczej konfiguracja (struktura), która jest gwarantem jedności jednostki? Jeśli uznać, że pierwszeństwo ma struktura, pojawia się pytanie o jej źródło, na które Jaworski odpowiada w następujący sposób:

W [mojej] wersji hylemorfizmu struktura sama w sobie, tak jak materiał budulcowy, jest podstawową zasadą, taką, która nie wymaga dalszego wyjaśnienia ... Pytanie, dlaczego istnieje struktura albo materiały budulcowe ... jest podobne do pytania, dlaczego istnieje wszechświat, albo dlaczego istnieje coś zamiast niczego ${ }^{27}$.

Wydaje się, że taka odpowiedź nie jest satysfakcjonująca z punktu widzenia filozofii oraz pytania o ostateczną naturę bytów oraz przyczyny ich stałości i zmienności. I choć Jaworski przyznaje otwarcie, że jego definicja formy substancjalnej znacząco odbiega od ujęcia klasycznego, to nie zmienia to faktu, że jego pozycja rodzi poważne zastrzeżenia z metafizycznego punktu widzenia.

\section{Hylemorfizm komplementarystyczny}

Kolejna reinterpretacja hylemorfizmu w filozofii analitycznej została zaproponowana przez Edwarda Jonathana Lowe. W opozycji do Koslicki Lowe podkreśla, że arystotelesowska koncepcja złożenia materii i formy wyklucza traktowanie ich jako „części składowych substancji, przynajmniej w potocznym rozumieniu 'części' i dodaje, że „prawdziwa jednostkowa substancja nie

26 "On the hylomorphic view, composition occurs when and only when an individual configures or structures materials" (ibidem, s. 160). W innym miejscu Jaworski dodaje: "Jednostki, które konfigurują materiały wchodzące w ich skład będę nazywał jednostkami ustrukturalizowanymi" (ibidem, s. 104).

27 "[O]n [my version of] the hylomorphic view, structure itself, like material, is a basic principle, one that stands in need of no further explanation. ... Asking why either structure or materials exist ... comes close to asking why the universe as a whole exists, or why there is something instead of nothing" (ibidem, s. 277-78). 
może zawierać innych substancji jako części” - co odróżnia ją od zbiorów czy pakietów złożonych $z$ indywidualnych substancji ${ }^{28}$.

Jednocześnie Lowe definiuje materię i formę jako „niekompletne jednostki bytowe, uzupełniające się w złożeniu substancjalnym", które może być zdefiniowane jako „złożenie elementów (items), z których żaden nie może istnieć w oderwaniu od drugiego"29. W swoich przykładach domu złożonego z cegieł, zaprawy i drewna oraz organizmu konia złożonego z mięśni, krwi i kości kładzie nacisk na organizację tych elementów. Z jednej strony, podkreślając niekompletność materii i formy, Lowe robi krok w stronę klasycznego hylemorfizmu. $Z$ drugiej strony, istotną słabością jego koncepcji jest brak jasnej definicji natury i sposobu istnienia niekompletnych jednostek bytowych (elementów) substan$\mathrm{cji}^{30}$. Poza tym, Lowe zdaje się nie dostrzegać różnicy między akcydentalnym charakterem formy domu a substancjalnym charakterem formy organizmu ożywionego jakim jest koń. W myśl hylemorfizmu w jego klasycznym ujęciu, jedność pierwszego jest jedynie przypadłościowa, podczas gdy jedność organiczna drugiego ma charakter substancjalny. Rozróżnienie to wydaje się być niezbędne dla właściwego rozumienia istoty złożenia hylemorficznego.

Podobną do Lowe wersję hylemorfizmu zaproponował Gordon Barnes. Zmagając się z pytaniem o charakter zasady formalnej - tj. o to, czy jest ona bytem, właściwością, zdarzeniem lub procesem - ostatecznie stwierdza, że musi być ona bytem, gdyż inaczej nie istniałaby. Przyjmując to założenie, Barnes sugeruje, żeby uznać za Franciszkiem Suárezem, iż forma jest „niekompletną substancją", która potrzebuje komplementarnej materii, aby utworzyć całościowy i kompletny byt ${ }^{31}$. Rozumiejąc substancję jako byt złożony, Barnes proponuje rozróżnienie między materią niezależną od substancji - tj. subatomowymi cząstkami elementarnymi, których tożsamość jest niezależna od bycia częścią większej całości - oraz materią zależną od substancji - tj. częściami bytu określonego przez formę substancjalną (np. ludzkie serce, płuca, nerki, itp. jako części człowieka).

Takie ujęcie przyczyny materialnej jest nie tylko kolejnym ukłonem w stronę mereologii oraz odejściem od arystotelesowskiej koncepcji materii pierwszej

28 E. J. Lowe, A Neo-Aristotelian Substance Ontology: Neither Relational nor Constituent, [w:] Contemporary Aristotelian Metaphysics, T. E. Tahko (red.), Cambridge 2011, s. 230-231.

29 Materia i forma to "'incomplete' entities, completed by each other in their union in that substance," gdzie substancja jest rozumiana jako "combination of items neither of which can exist independently of the other in just such combination", ibidem, s. 230, 236.

30 W tym kontekście zasadnym wydaje się pytanie o to czy i na ile stanowisko Lowe różni się od koncepcji-omówionego powyżej-hylemorfizmu mereologicznego lub strukturalnego.

31 Por. G. P. Barnes, The Paradoxes of Hylomorphism, "The Review of Metaphysics" t. 56, nr 3 (2003), s. 507-508. 
w stronę atomizmu. W kontekście całości refleksji Barnesa nad hylemorfizmem, proponowana przez niego redefinicja materii, prowadzi do radykalnie nieortodoksyjnego - z punktu widzenia ujęcia klasycznego - stwierdzenia, iż

[M] ateria budująca byt ludzki nie jest czystą potencjalnością ... [lecz] musi posiadać mnogość form substancjalnych, gdzie forma organizmu ludzkiego jest tylko jedną spośród nich ... A zatem, sugeruję, że jedna i ta sama część (parcel) podstawowej materii może być uformowana przez dwie różne formy substancjalne i dzięki temu wchodzić w skład dwóch odrębnych substancji ${ }^{32}$.

\section{Hylemorfizm reidentyfikacyjny}

Trzecia odmiana hylemorfizmu analitycznego o której wypada wspomnieć została zaproponowana przez Annę Marmodoro i - w porównaniu z dotychczas omówionymi stanowiskami autorstwa Koslicki, Fine, Johnston, Jaworskiego, Lowe czy Barnesa - wydaje się być znacznie bliższa klasycznej definicji Arystotelesa. W jednym ze swoich artykułów Marmodoro stwierdza:

[B]ycie ujednoliconym w spójną całość wiąże się z re-identyfikacją części w sposób, który sprawia, że nie mogą one istnieć poza całością. Części są re-identyfikowane w oparciu o jednoczącą zasadę całości, którą jest forma substancjalna. Raz zre-identyfikowane, nie mają już odrębności w substancji, istnieją w niej na sposób holistyczny ${ }^{33}$.

Kontynuując swoje rozważania, Marmodoro zauważa słusznie, że „dzielenie substancji generuje części, które nie są częściami substancji”, po czym definiuje formę substancjalną jako zasadę lub „działanie na elementach składowych substancji, ogałacające je z ich odrębności, raczej niż osobną kategorię (item) ontologiczną.” W podsumowaniu stwierdza, iż to „[r]e-identyfikacja, bardziej

32 "[T]he matter that composes a human being is not a mere potentiality. ... [It] must have a plurality of substantial forms, of which the form of a human being is only one. ... So I am suggesting that one and the same 'parcel' of basic matter can be informed by two distinct substantial forms and thereby compose two distinct substances", ibidem, s. 517, 520, przyp. 25. Stanowisko Barnesa w tej kwestii jest związane z jego radykalnym odrzuceniem arystotelesowsko-tomistycznej koncepcji obecności podstawowych elementów budulcowych w złożonych bytach poprzez ich moce (virtute).

33 "[B] eing unified into a whole re-identifies the parts in a way they cannot be when apart from the whole. The parts are re-identified according to the unifying principle of the whole, the substantial form. Once re-identified, they have no distinctness in the substance; they exist in it holistically." A. Marmodoro, Aristotle's Hylomorphism Without Reconditioning, "Philosophical Inquiry", t. 37, nr 1-2 (2013), s. 15. 
niż połączenie lub bycie w relacji, jest [zaproponowanym przez] Arystotelesa rozwiązaniem [problemu] jedności hylemorficznej”34.

Jakkolwiek pewne intuicje Marmodoro na temat formy i jedności substancjalnej wskazują na to, że jest ona bliżej klasycznego hylemorfizmu, wydaje się, że jej stanowisko nie jest wolne od mereologicznego rozumienia materii. Nawet jeśli w zaproponowanym przez nią ujęciu hylemorfizmu znajdujemy sformułowanie mówiące o "materii jako będacej potencjalnie formą" ${ }^{35}$, nie znajdziemy w nim definicji materii jako pierwszego substratu, czy też uwagi na temat tego, że re-identyfikacja części jest zmianą substancjalną możliwą dzięki materii pierwszej leżącej u podstaw każdej z nich.

\section{Podsumowanie}

W podsumowaniu naszej analizy stanowisk w ramach współczesnego hylemorfizmu analitycznego należy stwierdzić, że ich autorzy mają trudność w uwolnieniu się od myślenia w paradygmacie mereologicznym. Powszechne wśród nich definiowanie materii w odniesieniu do podstawowych fizykalnych (tj. empirycznie weryfikowalnych) jednostek budulcowych prostych i złożonych bytów we wszechświecie, sytuuje w efekcie ich propozycje po stronie wspólczesnych wersji atomizmu. Reprezentowany przez nich sposób rozumienia zasady formalnej jako części, niekompletnej jednostki bytowej, niekompletnej substancji, zasady lokalizacji składowych w strukturze całości bytu, lub zasady reidentyfikacji jego części, odbiega znacząco od definicji Arystotelesa oraz średniowiecznych komentatorów jego dzieł.

Wydaje się, że błąd współczesnych orędowników hylemorfizmu w filozofii analitycznej może polegać na ich powierzchownym odniesieniu się do arystotelesowskiej definicji materii i formy, na wzór interpretacji wspomnianej w pierwszej części artykułu. Widać to wyraźnie w stanowisku Jaworskiego, który - wyliczając cztery rodzaje przyczyn zaproponowane przez Arystotelesa - utożsamia zasadę formalną ze strukturą, natomiast zasadę materialną $z$ materią, która podlega procesom strukturalizacjii ${ }^{36}$. Takie ujęcie wydaje się pomijać to, co leży w samym sercu teorii hylemorfizmu Arystotelesa, tj. jego

$34 \quad$ W oryginale czytamy: 1) "partitioning a substance generates parts that are not parts of the substance;" 2) substantial form is a principle or "an operation on the elements of a substance, stripping them of their distinctness, rather than being an item in the ontology;" 3) "[r]e-identification, rather than combination or relationality, is Aristotle's solution to hylomorphic unity". Ibidem, s. 16-17.

35 Ibidem, s. 19.

36 Por. W. Jaworski, Structure, s. 206. 
definicję materii jako zasady potencjalności oraz formy jako zasady aktualizującej materię pierwszą.

\section{Hylemorfizm analityczny i problem relacji umysł-ciało}

Próbując odnieść omówione powyżej współczesne wersje hylemorfizmu do debaty nad problemem relacji umysł-ciało natrafiamy na poważne trudności. Ich mereologiczna orientacja w kwestii interpretacji przyczyny materialnej zbliża je do materializmu metafizycznego, podczas gdy prezentowane przez nie reinterpretacje przyczyny formalnej nie pozwalają sformułować jasnego stanowiska co do zasady jedności organizmu ludzkiego. W konsekwencji, teorie formy substancjalnej rozumianej jako część, niekompletna jednostka bytowa, niekompletna substancja, zasada strukturalnej orientacji części w obrębie całości, bądź też zasada reidentyfikacji części w obrębie całości, nie wydają się być także pomocne w odpowiedzi na pytanie o naturę umysłu. W myśl tych stanowisk umysł ludzki mógłby być zdefiniowany co najwyżej jako epifenomen zależności i zdarzeń mających miejsce na podstawowym poziomie złożoności fizykalnie rozumianej materii, włączonej jednocześnie w całościowo ujętą strukturę bytową organizmu ludzkiego.

\section{Propozycja Williama Jaworskiego}

Trudności neohylemorficznego stanowiska w kwestii umysłu oraz debaty na temat relacji umyst-ciało są dobrze widoczne w stanowisku Jaworskiego. Definiując organizmy żywe jako „strefy ustrukturalizowanej aktywności” ${ }^{37}$ traktuje on fenomen myślenia, czucia, percepcji, oraz działania intencjonalnego (zjawiska często określane mianem umysłowych lub psychicznych) jako „ustrukturalizowane manifestacje mocy” części składowych organizmu ludzkiego, w odpowiedzi na bodźce ze środowiska zewnętrznego ${ }^{38}$. Na innym miejscu określa je mianem ,wzorów oddziaływania społecznego i środowiskowego" ${ }^{39}$.

Jego pomysł na pozbycie się dychotomii między tym, co umysłowe i tym, co fizyczne polega na zatarciu granic w klasyfikacji i definiowaniu obu stron kartezjańskiego rozróżnienia. Z jednej strony, ponieważ myśli i uczucia są „,wcielone”

37 Ang. "zones of structured activity". W. Jaworski, Philosophy of Mind: A Comprehensive Introduction, John Wiley \& Sons 2011, s. 306.

38 Ang. "structured manifestations of powers" (W. Jaworski, Structure, s. 170). Por. także W. Jaworski, Powers, Structures, and Minds, [w:] Powers and Capacities in Philosophy: The New Aristotelianism, R. Groff, J. Greco (red.), New York 2013, s. 158.

39 Ang. "patterns of social and environmental interaction" (W. Jaworski, Philosophy, s. 306-307). 
(embodied), nie można ich określić mianem „nie-fizykalnych”. Z drugiej strony, ponieważ fundamentalne procesy fizyczne w ludzkim organizmie przyczyniają się do powstania - na wyższym poziomie analizy bytu człowieka - myśli czy uczuć, nie można ich traktować jako „nie-psychicznych”. W efekcie: „[a]ktywności ludzkie wyższego stopnia, jak również pod-struktury i pod-aktywności, które obejmują (which they comprise), mogą być wszystkie razem sklasyfikowane jako społeczne, psychologiczne, biologiczne, jak również fizykalne" ${ }^{40}$.

Taka próba rozwiązania problemu relacji umysł-ciało wydaje się być mało efektywna. Przypisywanie mereologicznym częściom organizmu ludzkiego zarówno cech fizykalnych, jak i umysłowych, jest bliskie panpsychizmowi, o który Jaworski oskarża - zresztą niesłusznie - klasyczny emergentyzm. Przesunięcie punktu ciężkości na strukturalną analizę złożonego bytu ludzkiego rodzi pytania podobne do tych, o których wspomnieliśmy powyżej. Nie jest też jasne, w jaki sposób ustrukturalizowanie czasowo-przestrzenne jest źródłem i gwarantem jedności bytów złożonych. Co więcej, jeżeli struktura poprzedza i jest zasadą jedności jednostki strukturalizującej (konfigurującej) materię, stanowisko Jaworskiego wymaga określenia zarówno źródła struktur w przyrodzie jak i ich ostatecznej natury ontologicznej (tego, czy są one materialne czy niematerialne). Wiemy już, że Jaworski nie daje odpowiedzi na te pytania. Nadaje pojęciu struktury status pojęcia pierwotnego, ucinając w ten sposób wszelką dyskusję nad genezą i naturą struktury.

\section{Hylemorfizm analityczny a pojęcie duszy ludzkiej}

Rozważając analityczne wersje hylemorfizmu, nie możemy pominąć pytania o pojęcie duszy ludzkiej, które stoi w samym centrum antropologii filozoficznej opartej na hylemorfizmie w jego ujęciu klasycznym. W kontekście naszych dotychczasowych refleksji staje się oczywisty fakt, że współcześni zwolennicy teorii materii i formy nie odwołują się do koncepcji duszy. Co więcej, prezentowana przez nich mereologiczna reinterpretacja przyczyny materialnej oraz propozycje redefinicji duszy jako części, niekompletnej jednostki bytowej lub niekompletnej substancji (o trudnej do określenia naturze ontologicznej), czy wreszcie zasady strukturalizującej, wydaje się być nie do pogodzenia z pojęciem

40 „Higher-level human activities, and the substructures and subactivities they comprise all count as social, psychological, biological, and also physical phenomena” (ibidem, s. 307). Wyciągając wnioski z tej konstatacji Jaworski stwierdza, że mózg ludzki nie tyle generuje stany umysłu, co raczej stanowi „pod-system” (subsystem) organizmu umożliwiający mu wchodzić w interakcje z innymi ludźmi oraz środowiskiem naturalnym w „wysoko ustrukturalizowany sposób" (in the highly structured ways), który określamy mianem „przekonania”, „pragnienia”, czy „bólu”. Por. ibidem, s. 308-309. Por. także W. Jaworski, Powers, s. 161-168; W. Jaworski, Structure, s. 170-177. 
duszy ludzkiej rozumianej jako szczególnego rodzaju zasada aktualizująca materię pierwszą.

W efekcie, władze intelektualne (umysłowe), które w ujęciu arystotelesowsko-tomistycznym są szczególnym rodzajem władz duszy, w ujęciu hylemorfizmu analitycznego stają się epifenomenalnymi właściwościami podstawowych fizykalnych elementów budujących organizm ludzki, ujętych (lub zre-identyfikowanych) w określonej strukturze czasowo-przestrzennej bądź uformowanych przez zasadę formalną o blizej niezdefiniowanym charakterze (tj. określaną jako mereologiczna część całości cechująca się pierwotną jednością, niekompletna jednostka bytowa, lub niekompletna substancja).

\section{Wnioski}

Nasze rozważania ukazały zasadniczą różnicę między klasycznym i współczesnym ujęciem hylemorfizmu i jego zastosowaniem w antropologii filozoficznej. Stanowisko hylemorfizmu analitycznego okazuje się być stosunkowo radykalną reinterpretacją mýśli klasycznej, prowadzącą do rezygnacji z odniesienia do kategorii duszy w inspirowanej przezeń koncepcji natury ludzkiej.

Niemniej jednak należy zauważyć i docenić główną motywację twórców hylemorfizmu analitycznego. Tym, co ich inspiruje, jest pragnienie znalezienia metafizycznej alternatywy dla materializmu eliminatywnego i reduktywnego (tożsamościowego). Ich nacisk na realność quasi-materialnej lub wprost niematerialnej zasady formalnej - rozumianej jako szczególnego rodzaju część całości cechująca się pierwotną jednością, niekompletna jednostka bytowa lub substancja, bądź też strukturalna orientacja w czasie i przestrzeni części złożonych bytów - jest próbą uzasadnienia stanowiska mówiącego, że organiczna całość jest czymś więcej niż fizyczną sumą części. Co więcej, sam fakt rezygnacji z odwołania do kategorii duszy umysłowej nie musi być w punkcie wyjścia dyskwalifikujący dla antropologii w ujęciu analitycznym.

Jednocześnie, trudności i nieścisłości, które charakteryzują hylemorfizm analityczny i opartą na nim koncepcję natury ludzkiej, wydają się wskazywać na to, że hylemorfizm w klasycznym ujęciu może być bardziej spójną i wciąż ade kwatną alternatywą dla wszelkiego rodzaju redukcjonizmów ontologicznych. Bardzo mocne przywiązanie zwolenników współczesnych wersji hylemorfizmu do mereologicznego spojrzenia na materię dowodzi tego, że stając w opozycji do materializmu, przynajmniej do pewnego stopnia, pozostają wciąż „więźniami” naturalizmu. Klasyczny hylemorfizm jest z pewnością wolny od podobnego błędu. Pozostaje mieć nadzieje, że współcześni entuzjaści metafizycznego dualizmu materii i formy odkryją na nowo jego klasyczną definicję i nawet jeśli jej nie 
zaakceptują, będą mieli większą świadomość starożytnych podstaw swojego stanowiska metafizycznego.

\section{Dodatek}

Definicje najważniejszych stanowisk w debacie dotyczącej relacji umysł-ciało:

1) materializm - zakłada istnienie jednego tylko rodzaju bytów we wszechświecie, tj. bytów materialnych, w myśl stwierdzenia Epikura mówiącego, iż całość świata jest złożeniem ciał (materii) oraz próżni, stanowisko to jest formą monizmu ontologicznego i występuje w przynajmniej dwóch wersjach:

(1a) materializm eliminacyjny (fizykalizm) - wszystko to, co w naszym opisie rzeczywistości ma charakter pozamaterialny jest jedynie mniej lub bardziej użyteczną fikcją,

(1b) materializm redukcyjny (tożsamościowy) - pozamaterialne aspekty rzeczywistości (w tym umysł) istnieją realnie, choć jednocześnie są w pełni tożsame oraz możliwe do wytłumaczenia w oparciu o materialne (fizykalne) składniki otaczającego nas świata;

2) dualizm - zakłada istnienie więcej niż jednego tylko rodzaju przypadłości lub bytów we wszechświecie, występuje w dwóch wersjach:

(2a) dualizm przypadłościowy - jeden i ten sam byt ludzki o fizykalnej naturze cechują dwojakiego rodzaju cechy: fizykalne (masa, ładunek, pozycja, itp.) oraz niefizykalne, tj. umysłowe (uczucia, myśli, itp.),

(2b) dualizm substancjalny - ludzki umysł i ciało są dwoma odrębnymi substancjami: niefizykalną (duchową) oraz fizykalną;

3) behawioryzm logiczny - stanowisko odrębne od behawioryzmu psychologicznego (często klasyfikowane jako kolejna wersja materializmu), zakładające, iz - jakkolwiek umysł, akty woli, czy uczucia są prawdziwe - w istocie są one funkcjonalnym skrótem w opisie pewnych odpowiedzi o charakterze fizykalnym na poziomie fizjologii organizmów zwierzęcych i ludzkich - definiowanych na podstawie korelacji input-output;

4) instrumentalizm - stanowisko zbliżone materializmu eliminatywnego uznające, że cały dyskurs dotyczący fenomenu umysłu i stanów psychologicznych jest nie tyle mniej lub bardziej użyteczną fikcją (co wiązałoby się $z$ tym, że w efekcie można się go pozbyć) lecz użytecznym instrumentem w przewidywaniu ludzkich zachowań;

5) monizm anomalny - wszystkie zdarzenia w przyrodzie są opisywalne na poziomie fizykalnym, podczas gdy niektóre z nich mogą być też opisane 
jako umysłowe, i choć ontologicznie rzecz ujmując wszystkie zdarzenia mają charakter czysto fizykalny (monizm) należy dopuścić anomalię opisu części z nich jako zdarzeń umysłowych - stanowisko bliskie, aczkolwiek różne od materializmu eliminatywnego oraz dualizmu przypadłościowego;

6) multiple-realizability argument - każde zjawisko określane mianem umysłowego (psychologicznego), choć ma swoje podłoże w czysto fizykalnych oddziaływaniach na podstawowych poziomach organizacji materii, jest jednocześnie realizowalne na wiele różnych sposobów, co nie pozwala go ostatecznie zredukować (w odróżnieniu od materializmu eliminatywnego);

7) stanowisko superweniencji - rozróżniając poziom podstawowy $(A)$ i wyższy $(B)$ organizacji materii (oraz cechujące je zjawiska o charakterze czysto fizykalnym oraz umysłowym), można zaobserwować ścisłą zależność pomiędzy $A$ i $B$ polegającą na tym, że każda zmiana w A związana jest $z$ korespondującą zmianą w $B$ i vice versa (brak jasności i jedności między zwolennikami superweniencji co do charakteru powiązania zjawisk na obu poziomach);

8) emergentyzm - rozróżniając poziom podstawowy (A) i wyższy (B) złożoności materii, stanowisko to zakłada, iż na wyższych poziomach organizacji możemy obserwować nowe i nieredukowalne struktury, bądź właściwości bytów, które wiążą się z nowym i nieredukowalnym rodzajem przyczynowości biegnącej z góry na dół (top-down causality), w odróżnieniu od zależności przyczynowych łączących poziom podstawowy z wyższym (bottom-up causality), zwolennicy i znawcy emergentyzmu odróżniają jego wersję epistemologiczną (przyjęcie teorii struktur emergentnych jest podyktowane ograniczonym stanem wiedzy badawczej i w związku z tym ma charakter redukowalny i tymczasowy) od ontologicznej (zjawisko emergencji ma charakter ontologiczny i nieredukowalny).

Słowa kluczowe: dusza ludzka, hylemorfizm analityczny, hylemorfizm klasyczny, intelektualne władze duszy ludzkiej, William Jaworski.

\section{Bibliografia:}

\section{Skróty odnośników oraz bibliografia dzieł} Arystotelesa i św. Tomasza z Akwinu:

1. De an. - Arystoteles, O Duszy, tłum. P. Siwek, [w:] Arystoteles, Dzieła wszystkie, t. 3, 33-146, Warszawa 1992.

2. De gen. et corr. - Arystoteles, O Powstawaniu i niszczeniu, thum. L. Regner, [w:] Arystoteles, Dzieła Wszystkie, t. 2, 353-424, Warszawa 1990. 
3. Meta. - Arystoteles, Metafizyka, tłum. K. Leśniak, [w:] Arystoteles, Dzieła Wszystkie, t. 2, 615-857, Warszawa 1990.

4. Phys. - Arystoteles, Fizyka, tłum. K. Leśniak, [w:] Arystoteles, Dzieła Wszystkie, t. 2, 23-204, Warszawa 1990.

5. De prin. nat. - Tomasz z Akwinu, De principiis naturae, t. 43 Opera Omnia, 39-47, Rzym 1976.

6. In De an. - Tomasz z Akwinu, In Aristotelis librum De anima commentarium, t. 45/1 Opera Omnia, Rzym 1984.

7. ST - Tomasz z Akwinu, Summa theologiae, Rzym 1962. [Tłumaczenie polskie: Tomasz z Akwinu, Traktat o Człowieku, tłum. S. Swieżawski, Kęty 2000].

\section{Pozostałe pozycje bibliograficzne:}

1. Barnes G. P., The Paradoxes of Hylomorphism, "The Review of Metaphysics" t. 56, nr 3 (2003), s. 501-523.

2. Brower J. E, Aquinas's Ontology of the Material World: Change, Hylomorphism, and Material Objects, New York 2014.

3. Feser E., Scholastic Metaphysics: A Contemporary Introduction. Heusenstamm 2014.

4. Fine K., Things and Their Parts, „Midwest Studies in Philosophy” t. 23, nr 1 (1999), s. 61-74.

5. Jaworski W., Philosophy of Mind: A Comprehensive Introduction, Oxford 2011.

6. Jaworski W., Powers, Structures, and Minds, [w:] R. Groff, J. Greco (red.), Powers and Capacities in Philosophy: The New Aristotelianism, New York 2013, s. 145-171.

7. Jaworski W., Structure and the Metaphysics of Mind: How Hylomorphism Solves the Mind-Body Problem, Oxford 2016.

8. Johnston M., Hylomorphism, „Journal of Philosophy” t. 103, nr 12 (2006), s. 652-698.

9. Kenny A., Aquinas on Mind, London - New York 1993.

10. Koslicki K., The Structure of Objects, Oxford 2010.

11. Loux M. J., Aristotle's Hylomorphism, [w:] D. D. Novotný, L. Novák (red.), Neo-Aristotelian Perspectives in Metaphysics, New York 2014, s. 138-163.

12. Lowe E. J., A Neo-Aristotelian Substance Ontology: Neither Relational Nor Constituent, [w:] T. E. Tahko (red.), Contemporary Aristotelian Metaphysics, Cambridge 2011, s. 229-248.

13. Madden J. D., Mind, Matter, and Nature: A Thomistic Proposal for the Philosophy of Mind, Washington, D.C. 2013.

14. Marmodoro A., Aristotle's Hylomorphism Without Reconditioning, „Philosophical Inquiry" t. 37, nr 1-2 (2013), s. 5-22.

15. Oderberg D. S., Real Essentialism, New York 2007.

16. Shanley B. J., Tradycja Tomistyczna, tłum. R. Mordarski, Poznań 2017. 